\title{
Use of stable isotopes to quantify seasonal changes of trophic niche and levels of population and individual specialisation in seabirds
}

\author{
Audrey Jaeger ${ }^{1, *}$, Maëlle Connan ${ }^{1}$, Pierre Richard ${ }^{2}$, Yves Cherel ${ }^{1}$ \\ ${ }^{1}$ Centre d'Etudes Biologiques de Chizé, UPR 1934 du CNRS, 79360 Villiers-en-Bois, France \\ ${ }^{2}$ Laboratoire Littoral, Environnement et Sociétés, UMR 6250 du CNRS-Université de La Rochelle, 2 Rue Olympe de Gouges, \\ 17000 La Rochelle, France
}

\begin{abstract}
Niche variation is a widespread phenomenon that has important implications for ecological interactions and conservation biology, but few studies have quantified the trophic niche width (TNW) and its within- and between-individual components. We used stable isotopes of body feathers to investigate (1) seasonal isotopic niche changes of 4 southern procellariiforms and, (2) the level to which individuals are specialised relative to their population within each season. (1) $\delta^{13} \mathrm{C}$ and $\delta^{15} \mathrm{~N}$ values of chicks and adults indicated a well-defined trophic segregation within the seabird assemblage during both the breeding and poorly known moulting (inter-nesting) periods, and they underlined marked species-specific seasonal changes. One species (light-mantled sooty albatross) remained within the Southern Ocean both during breeding and body feather moult, while the 3 others migrated either to oceanic subtropical waters (wandering and sooty albatrosses) or high isotopic marine areas (e.g. productive neritic waters; white-chinned petrel) during the moulting period. (2) Isotopic variances and TNW were generally low, indicating that birds belong to isotopic specialist populations within a given period. Variances and TNW were larger for white-chinned petrel chicks and light-mantled sooty albatross adults, respectively, indicating isotopic generalist populations and revealing 2 new foraging behaviours. Individual white-chinned petrel chicks segregated by their feather isotopic signatures, thus indicating individual/pair specialisation of parent birds during the chick-rearing period. The light-mantled sooty albatross population included mostly isotopic generalist individuals during the moulting period, with individuals using different habitats and diets. The study highlights the utility of feather isotopic signature for determining TNW and points out the necessity to develop such new approaches to better depict niche variations at both population and individual levels.
\end{abstract}

KEY WORDS: Procellariiform - Inter-nesting period • Body feather • Specialist • Generalist • Southern Ocean

Resale or republication not permitted without written consent of the publisher

\section{INTRODUCTION}

Stable isotope analysis has emerged as a key tool for ecologists, and the concept of isotopic niche is a powerful way to investigate ecological niches (Newsome et al. $2007)$. Stable carbon $\left(\delta^{13} C\right)$ and nitrogen $\left(\delta^{15} N\right)$ isotope ratios of consumers define the isotopic niche along 2 dimensions, with $\delta^{13} \mathrm{C}$ and $\delta^{15} \mathrm{~N}$ values reflecting the consumers' foraging habitat and trophic position, respectively. Consumer tissues are stepwise-enriched in ${ }^{15} \mathrm{~N}$ relative to their food and consequently $\delta^{15} \mathrm{~N}$ measure- ments serve as indicators of a consumer's trophic level (McCutchan et al. 2003). In contrast, $\delta^{13} \mathrm{C}$ values vary little along the food chain and are mainly used to determine carbon sources in a trophic network (McCutchan et al. 2003) and foraging habitats in the marine environment (Hobson et al. 1994, Cherel \& Hobson 2007).

Isotopic analysis of feathers is beginning to yield important insights into the ecology of birds, including resource partitioning within communities (Cherel et al. 2008b) and determination of migratory connectivity and seasonal interactions (Rubenstein \& Hobson 2004). 
The basic underlying principle is that the isotopic composition of feathers reflects diet at the time of feather growth, because keratin is metabolically inert after synthesis (Rubenstein \& Hobson 2004). Feather $\delta^{13} \mathrm{C}$ and $\delta^{15} \mathrm{~N}$ values of chicks are representative of the species' isotopic niche during breeding. In contrast, the stable isotopic signature of adult feathers is a powerful tool to investigate the poorly known inter-nesting foraging habitats and diets of seabirds (Cherel et al. 2006, Hedd \& Montevecchi 2006, Gladbach et al. 2007), because the adult moult occurs primarily during the non-breeding period (Warham 1990, 1996, Bridge 2006). Chick and adult feathers therefore allow the determination of seasonal changes in the species' isotopic niche (Cherel et al. 2000). Characterisation of seasonal niche variations in seabirds is of paramount importance, because environmental variability and human factors (e.g. fisheries) during the inter-nesting period shape their population dynamics (Barbraud \& Weimerskirch 2003, Grosbois \& Thompson 2005, Rolland et al. 2008). This is particularly relevant for the highly pelagic procellariiforms (albatrosses and petrels), which are among the most threatened taxa of birds (BirdLife International 2008, www.birdlife.org).

Niche variation is a widespread phenomenon among species. A bias in most studies is that conspecific individuals are considered as ecologically equivalent, while there is increasing evidence that individuals within a population vary considerably in the way they use habitats and resources. Documenting the incidence and level of niche variation and individual specialisation is therefore a first step towards understanding their basis and implications for community ecology and conservation biology (Durell 2000, Bolnick et al. 2003). Stable isotopes are well suited for quantifying foraging strategies at both the individual and population levels, with variance in isotopic ratios among individuals being a useful proxy for trophic niche width (Bearhop et al. 2004). Hence, a preliminary feather isotopic investigation described diverse species-specific and individual foraging strategies in seabirds (Cherel et al. 2006), but the procedure did not allow a quantification of the within- and between-individual components (WIC and BIC) of trophic niche width (TNW) (Bolnick et al. 2003). We consequently developed a 2step procedure using $\delta^{13} \mathrm{C}$ and $\delta^{15} \mathrm{~N}$ values of adult body feathers as continuous niche axes (Bolnick et al. 2002) to determine trophic niche at the population and individual levels during the moulting period (Jaeger et al. 2009).

Our main goal was to apply this recently described procedure on some threatened species of albatrosses and petrels, focusing on the poorly documented but crucial inter-nesting period. The work was conducted on an assemblage of large procellariiforms breeding at Crozet
Islands, southern Indian Ocean, including the whitechinned petrel Procellaria aequinoctialis (WCP) and 3 albatrosses: the wandering albatross Diomedea exulans (WA), sooty albatross Phoebetria fusca (SA), and lightmantled sooty albatross Phoebetria palpebrata (LMSA). The species are impacted by both commercial fisheries and environmental changes, and recent estimations have revealed increases (LMSA), recovering (WA) or sharp decreases (SA, WCP) in their breeding populations (Barbraud et al. 2008, Delord et al. 2008). We first determined the species' isotopic niche and trophic structure of the assemblage during breeding using chick body feathers. In a second step, species' isotopic niches during moult were determined using adult body feathers. Thirdly, breeding and moulting isotopic niches were compared in order to assess seasonal changes in the species' foraging ecology. Fourthly, adult TNW (and WIC and BIC) were used to quantify the degree of specialisation in habitat/diet at the population and individual levels during the moulting period.

\section{MATERIALS AND METHODS}

The field study was carried out on Possession Island $\left(46^{\circ} 30^{\prime} \mathrm{S}, 51^{\circ} 45^{\prime} \mathrm{E}\right)$, Crozet Archipelago. The southwestern Indian Ocean is marked by the strong confluence of the Subantarctic and Subtropical Fronts; consequently, the Subantarctic Zone here includes water masses between the Subtropical Front and the Polar Front (Park \& Gambéroni 1997), where Crozet Islands are located (Fig. 1). The Southern Ocean is defined as the ocean south of the Subtropical Front, and the Subtropical and Antarctic Zones, as the zones north of the Subtropical Front and south of the Polar Front, respectively (Fig. 1).

The assemblage of albatrosses breeding at Possession Island is mainly composed of WA, SA and LMSA with $\sim 580, \sim 100$ and $\sim 1370$ breeding pairs in 2005, respectively (Delord et al. 2008). The WCP population at Possession Island was recently estimated at $\sim 5800$ pairs (Barbraud et al. 2008). The 4 species belong to the same guild of large procellariiforms that forage over wide ocean areas during the breeding period. They breed sympatrically during summer, but the long breeding cycle of WA also includes the winter months. The 3 albatross species are biennial breeders if they successfully raised their chicks, while WCP breed annually (Warham 1990).

Body feathers grown during the inter-nesting period were used because their isotopic composition was not significantly different from that of wing feathers in breeding albatrosses, being thus a safe alternative to flight feathers whose collection impairs the birds' flying ability (Jaeger et al. 2009). Back body feathers 


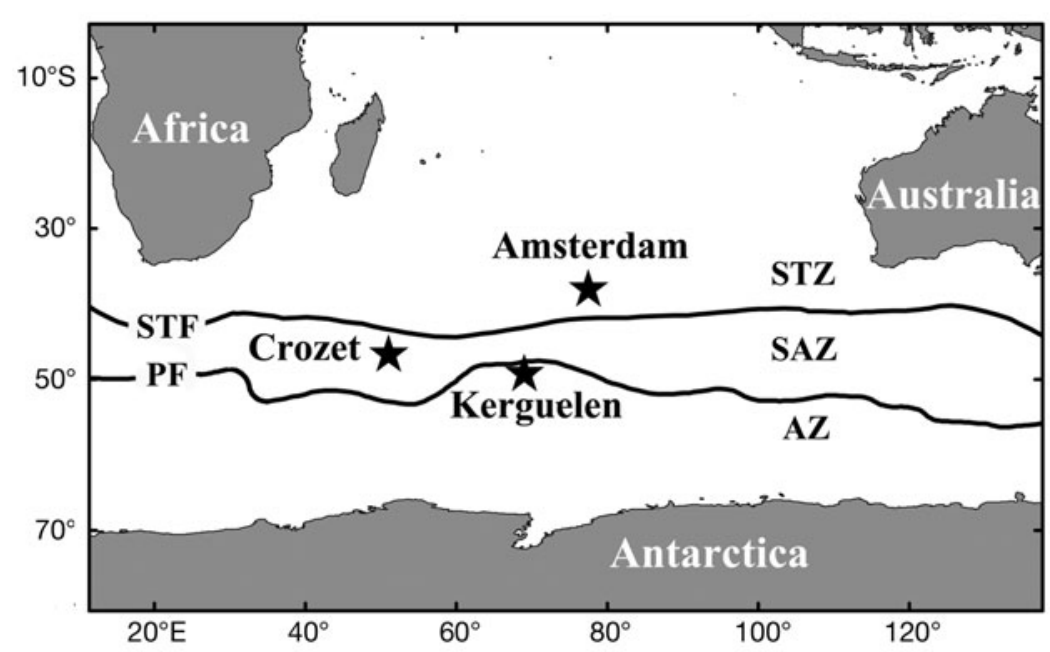

Fig. 1. Location of the Crozet Archipelago (46 $\left.30^{\prime} \mathrm{S}, 51^{\circ} 45^{\prime} \mathrm{E}\right)$ and of the main oceanic fronts and zones in the western Indian Ocean. Abbreviations: STF, Subtropical Front; PF, Polar Front; STZ, Subtropical Zone; SAZ, Sub-antarctic Zone; AZ, Antarctic Zone (Park \& Gambéroni 1997)

were sampled from 10 to 21 randomly chosen individuals for each group of chicks and adults (see Table 1). All species were studied within the same year (2005). Chick feathers were sampled at the end of the chickrearing period (March to April for SA, LMSA and WCP, and September for WA) and adult feathers during incubation (October to December).

Following the procedure of Jaeger et al. (2009), $\delta^{13} \mathrm{C}$ and $\delta^{15} \mathrm{~N}$ variations were used to define the level of within-season specialisation in habitat and diet, respectively. Isotopic measurements were first made on a single whole body feather per bird to define isotopic specialist populations (low TNW) from isotopic generalist populations (high TNW), with TNW being the variance among all feathers of a given species. In a second step and for generalist populations only, measurements on 3 additional feathers per bird were used to delineate isotopic individual specialists (low WIC, high BIC) from isotopic individual generalists (high WIC, low BIC). WIC is the average variance of 4 individual feathers and BIC the variation among means of 4 individual feathers (Bolnick et al. 2003). The relative degree of individual specialisation was subsequently measured as the proportion of TNW explained by within-individual variation, WIC/TNW (WIC/TNW varies from 0 [maximum variation among individuals] to 1 [no variation among individuals]; Bolnick et al. 2002, 2003). Using the isotopic method, an individual specialist is here a bird with a diet/habitat that does not differ in mean isotopic value within a particular season, whereas an individual generalist refers to a bird that shows high within-season variability in diet/habitat.

Three important limitations linked to moult timing and chronologies need to be taken into account.
(1) The little information available about the moulting process of large procellariiforms indicates that body feathers are replaced gradually over several months, probably during the whole inter-nesting period (Warham 1996). In the present work, the duration of the inter-nesting period depends on the species, spanning 1 winter (WCP), 1 full year (WA), and 1 full year plus 1 winter (SA and LMSA). Moreover, the precise timing of synthesis of each body feather during the internesting period is not known. Consequently, the temporal window covered by analysing 1 (or several) body feathers is probably different between individuals and between species. We therefore describe isotopic niches for each species' respective body feather moult period, and realise that those periods may not represent the same proportion of the inter-nesting period among species. Further research is needed to determine whether the temporal extent of body feather moult is sufficient to appropriately reflect the whole inter-nesting period.

(2) The duration of growth of 1 given body feather of adults and chicks is not known. In seabirds, flight feathers grow $\sim 6 \mathrm{~mm}$ per day (Bridge 2006), and, in birds, body feathers grow at a slower rate than primaries (Widelitz et al. 2003). Consequently, a 6 to $10 \mathrm{~cm}$ long body feather takes at least 2 to $3 \mathrm{wk}$ to grow.

(3) The isotopic signature of chick feathers represents that of food brought back to the colony by the 2 parents. Moreover, chick body feathers grow during a more restricted period (second part of chick-rearing period) than adult feathers. Hence, the timing of growth of body feathers overlaps greatly during chick moult, thus precluding an accurate estimate of TNW, WIC and BIC. TNW of chicks was therefore not calculated, but we looked carefully at their isotopic variances, as they may indicate either individual and/or pair specialisations of the adults during the chick-rearing period.

To help interpretation of the $\delta^{13} \mathrm{C}$ values of the wideranging procellariiforms, feather isotopic values of 3 species spanning a latitudinal gradient in carbon stable isotopes (Cherel \& Hobson 2007) were used (see Figs. $2 \& 4$ ). These included chicks of the yellow-nosed albatross from Amsterdam Island $\left(37^{\circ} 5^{\prime} \mathrm{S}\right)$ and of the snow petrel from Adélie Land $\left(66^{\circ} 4^{\prime} \mathrm{S}\right)$, which indicated foraging in the Subtropical (Pinaud et al. 2005) and high-Antarctic Zones (Ridoux \& Offredo 1989), respectively (authors' unpubl. data, $\mathrm{n}=12$ and 18 , $\delta^{13} \mathrm{C}=-17.7 \pm 0.4$ and $-23.4 \pm 0.2 \%$, respectively). The 
third control species, the king penguin, is known to forage at the Polar Front (Bost et al. 1997) (authors' unpubl. data, $\mathrm{n}=12$ adults, $\delta^{13} \mathrm{C}=-21.2 \pm 0.4 \%$ o).

Prior to isotopic analysis, feathers were cleaned of surface lipids and contaminants using a 2:1 chloroform:methanol solution for $2 \mathrm{~min}$, followed by 2 successive methanol rinses. Each whole body feather was air dried and then homogenised by cutting it into very small pieces that were pooled. One sub-sample of each homogenised feather was then weighed ( 0.4 mg) with a microbalance and packed into a tin container, and nitrogen and carbon isotope ratios were determined with a continuous flow mass spectrometer (Micromass Isoprime) coupled to an elemental analyser (Euro Vector EA 3024). Results are presented in the usual $\delta$ notation relative to PeeDee Belemnite and atmospheric $\mathrm{N}_{2}$ for $\delta^{13} \mathrm{C}$ and $\delta^{15} \mathrm{~N}$, respectively. Replicate measurements of internal laboratory standards (acetanilide) indicated measurement errors of $<0.15 \%$ and $<0.20 \%$ for $\delta^{13} \mathrm{C}$ and $\delta^{15} \mathrm{~N}$, respectively. All data were analysed statistically using Matlab (7.0). All analyses related to species' isotopic niche description and segregation were performed with 1 feather per individual. Values are mean $\pm \mathrm{SD}$.

\section{RESULTS}

\section{Isotopic niches and segregation during the breeding and inter-nesting periods}

During breeding, sympatric albatrosses and WCP were segregated by both the $\delta^{13} \mathrm{C}$ and $\delta^{15} \mathrm{~N}$ values of their chicks ( 1 feather per individual; Kruskal-Wallis, $H_{3,47}=36.82$ and 37.47, respectively, both $\mathrm{p}<0.0001$ ).
Chick $\delta^{13} \mathrm{C}$ and $\delta^{15} \mathrm{~N}$ values characterised 3 distinct isotopic niches that differed by at least one isotopic axis. Feather $\delta^{13} \mathrm{C}$ and $\delta^{15} \mathrm{~N}$ values of LMSA and WCP were not significantly different (Multiple comparison tests of mean ranks, both $\mathrm{p}=1.000$ ), but their $\delta^{13} \mathrm{C}$ values differed by $\sim 2 \%$ from those of WA and SA chicks (all p < $0.001)$, with the 2 latter species segregating by their $\delta^{15} \mathrm{~N}(0.8 \%$, $\mathrm{p}=0.033)$ but not their $\delta^{13} \mathrm{C}(\mathrm{p}=1.000)$ values (Table 1, Fig. 2).

The species were also segregated by their feather isotopic signatures during the adult moulting period (Kruskal-Wallis, $H_{3,42}=37.42$ and 38.73 for $\delta^{13} \mathrm{C}$ and $\delta^{15} \mathrm{~N}$ values respectively, both $\left.\mathrm{p}<0.0001\right)$, which defined 4 distinct isotopic niches. The $\delta^{13} \mathrm{C}$ values of WA and SA adults were not statistically different (multiple comparison tests of mean ranks, $\mathrm{p}=1.000$ ), but all the other feather $\delta^{13} \mathrm{C}$ values differed significantly (Multiple comparison tests of mean ranks, all $\mathrm{p} \leq 0.027$ ). WA and SA however segregated by their $\delta^{15} \mathrm{~N}$ values (Multiple comparison tests of mean ranks, $\mathrm{p}=0.042$ ). Feather $\delta^{15} \mathrm{~N}$ values of LMSA and SA, and of WA and WCP were not statistically different (multiple comparison tests of mean ranks, $\mathrm{p} \geq 0.206$ ), but the 4 other pair comparison tests were significant (multiple comparison tests of mean ranks, all $\mathrm{p} \leq 0.042$ ) (Table 1, Fig. 2).

Seasonal variations in $\delta^{13} \mathrm{C}$ and $\delta^{15} \mathrm{~N}$ values within each species showed contrasting patterns (Table 1, Fig. 2). Isotopic signatures of feathers of LMSA adults and chicks were not significantly different (MannWhitney, $\mathrm{p}=0.173$ and 0.597 for $\delta^{13} \mathrm{C}$ and $\delta^{15} \mathrm{~N}$ values, respectively), while they differed greatly for the 3 other species (all $\mathrm{p}<0.001$ ). Both $\delta^{13} \mathrm{C}$ and $\delta^{15} \mathrm{~N}$ values of adult feathers were higher than in chick feathers in SA, WA, and WCP. WCP showed the largest isotopic increases between chick and adult feathers (7.0 and

Table 1. Diomedea exulans, Phoebetria fusca, Phoebetria palpebrata and Procellaria aequinoctialis. Stable carbon and nitrogen isotope values of body feathers of large procellariiforms from Possession Island. ${ }^{* * *}$ and NS indicate a significant difference and no statistical difference, respectively (Mann-Whitney $U$-test, $\mathrm{p}<0.001$ and $\mathrm{p}>0.05$, respectively) between chick and adult feathers of a given species. Trophic niche width (TNW), and between- and within-individual components (BIC and WIC) were calculated using 1 and 4 body feathers, respectively (see 'Materials and methods'). Values are mean \pm SD

\begin{tabular}{|c|c|c|c|c|c|c|c|c|}
\hline Species & Status & $\mathrm{n}$ & $\delta^{13} \mathrm{C}(\%)$ & $\delta^{15} \mathrm{~N}(\%)$ & $\begin{array}{l}\text { TNW (\%o) } \\
\left(\delta^{13} \mathrm{C} / \delta^{15} \mathrm{~N}\right)\end{array}$ & $\begin{array}{l}\text { WIC (\%o) } \\
\left(\delta^{13} \mathrm{C} / \delta^{15} \mathrm{~N}\right)\end{array}$ & $\begin{array}{c}\mathrm{BIC}(\%) \\
\left(\delta^{13} \mathrm{C} / \delta^{15} \mathrm{~N}\right)\end{array}$ & $\begin{array}{l}\text { WIC/TNW } \\
\left(\delta^{13} \mathrm{C} / \delta^{15} \mathrm{~N}\right)\end{array}$ \\
\hline Wandering albatross & $\begin{array}{l}\text { Chicks } \\
\text { Adults }\end{array}$ & $\begin{array}{l}21 \\
12\end{array}$ & $\begin{array}{c}-19.4 \pm 0.4 \\
-17.1 \pm 0.7 \\
* * *\end{array}$ & $\begin{array}{c}13.9 \pm 0.3 \\
15.7 \pm 0.7 \\
* * * *\end{array}$ & $\stackrel{-}{0.5 / 0.5}$ & $\begin{array}{l}- \\
-\end{array}$ & $\begin{array}{l}- \\
-\end{array}$ & $\begin{array}{l}- \\
-\end{array}$ \\
\hline Sooty albatross & $\begin{array}{l}\text { Chicks } \\
\text { Adults }\end{array}$ & $\begin{array}{l}10 \\
12\end{array}$ & $\begin{array}{c}-19.1 \pm 0.5 \\
-17.0 \pm 0.6 \\
* * *\end{array}$ & $\begin{array}{c}13.1 \pm 0.5 \\
14.5 \pm 0.5 \\
* * *\end{array}$ & $\frac{-}{0.4 / 0.3}$ & $\begin{array}{l}- \\
-\end{array}$ & $\begin{array}{l}- \\
-\end{array}$ & $\begin{array}{l}- \\
-\end{array}$ \\
\hline Light-mantled sooty albatross & $\begin{array}{l}\text { Chicks } \\
\text { Adults }\end{array}$ & $\begin{array}{l}10 \\
10\end{array}$ & $\begin{array}{c}-21.3 \pm 0.5 \\
-20.5 \pm 2.1 \\
\text { NS }\end{array}$ & $\begin{array}{c}12.4 \pm 0.4 \\
11.9 \pm 2.1 \\
\text { NS }\end{array}$ & $\begin{array}{c}- \\
3.9 / 3.6\end{array}$ & $\begin{array}{c}- \\
2.6 / 2.1\end{array}$ & $1.3 / 1.5$ & $\begin{array}{c}- \\
0.7 / 0.6\end{array}$ \\
\hline White-chinned petrel & $\begin{array}{l}\text { Chicks } \\
\text { Adults }\end{array}$ & $\begin{array}{l}10 \\
10\end{array}$ & $\begin{array}{c}-21.2 \pm 0.8 \\
-14.2 \pm 0.2 \\
* * *\end{array}$ & $\begin{array}{c}12.2 \pm 0.7 \\
16.7 \pm 0.5 \\
* * * *\end{array}$ & $\begin{array}{c}- \\
0.1 / 0.2\end{array}$ & $\begin{array}{l}- \\
-\end{array}$ & $\begin{array}{l}- \\
-\end{array}$ & $\begin{array}{l}- \\
-\end{array}$ \\
\hline
\end{tabular}




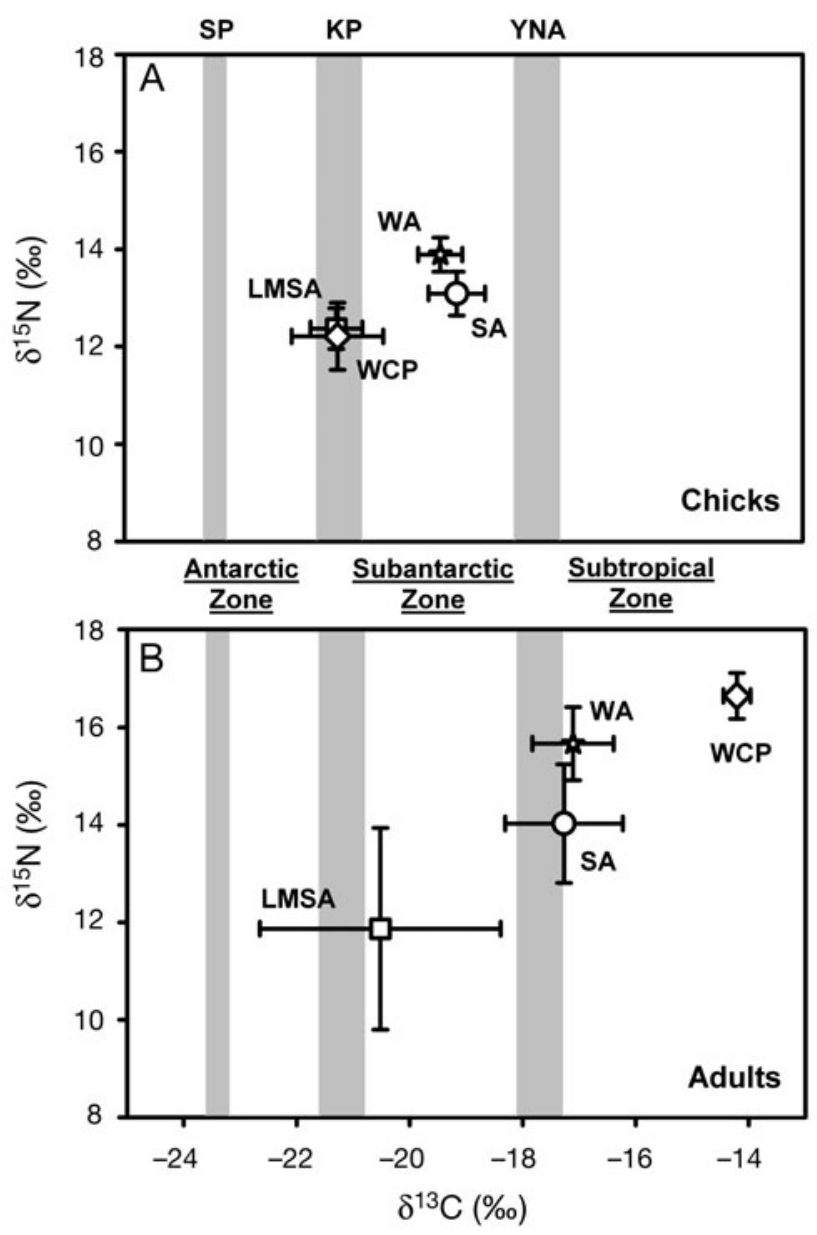

Fig. 2. Diomedea exulans, Phoebetria fusca, Phoebetria palpebrata and Procellaria aequinoctialis. Stable carbon and nitrogen isotope values of body feathers of large procellariiforms from Possession Island. (A) Chick feathers and (B) adult feathers show the species' isotopic niches during the breeding and moulting (inter-nesting) periods, respectively. Estimated foraging zones are indicated between the 2 panels. The signatures of snow petrels (SP), king penguins (KP) and yellow-nosed albatrosses (YNA) illustrate the $\delta^{13} \mathrm{C}$ values of species known to forage in the high-Antarctic Zone, at the Polar Front and in the Subtropical Zone, respectively (grey bars represent the species' $\delta^{13} \mathrm{C}$ standard deviations). Abbreviations: LMSA, light-mantled sooty albatross; SA, sooty albatross; WA, wandering albatross; WCP, white-chinned petrel. Values are mean $\pm \mathrm{SD}$

$4.5 \%$ for $\delta^{13} \mathrm{C}$ and $\delta^{15} \mathrm{~N}$ values, respectively) compared to WA and SA (2.3 and 2.1\%, and 1.8 and $1.4 \%$ for $\delta^{13} \mathrm{C}$ and $\delta^{15} \mathrm{~N}$ values, respectively).

\section{Isotopic variance and trophic niche width during the breeding and moulting periods}

Two important features arose concerning isotopic chick variances and adult TNW of the albatrosses and petrel (Table 1). First, variances and TNW were generally low for both adults and chicks. Second, 2 exceptions were the very large TNW of LMSA adults and the relatively high variance of WCP chicks compared to other adult and chick groups, respectively. Following our 2-step protocol (Jaeger et al. 2009), the isotopic signature of 3 additional body feathers (for a total of 4 feathers per individual) were therefore measured for LMSA adults and WCP chicks. Individual WCP chicks segregated by both their $\delta^{13} \mathrm{C}$ and $\delta^{15} \mathrm{~N}$ values (Kruskal-Wallis, $H_{9,30}=37.25$ and 35.37, both $\mathrm{p}<$ $0.0001)$, thus indicating individual/pair specialisation (Fig. 3). Interestingly, the $\delta^{13} \mathrm{C}$ and $\delta^{15} \mathrm{~N}$ values of all body feathers were linearly and positively correlated ( $n=40$, Generalized Linear Model with individuals as random factor, $\mathrm{p}<0.0001)$.

The WIC/TNW ratio of LMSA adults was moderate, indicating both significant intra- and inter-individual variations in their moulting isotopic niche. Most individual birds showed large variances, thus inducing large inter-individual overlaps in their isotopic niches (Fig. 4A). A hierarchical clustering analysis (Ward's method) performed using the $\delta^{13} \mathrm{C}$ and $\delta^{15} \mathrm{~N}$ values of all the 40 body feathers identified 3 groups of feathers, which segregated by their isotopic signatures (Kruskal-Wallis, $H_{2,37}=25.29$ and 21.75 for $\delta^{13} \mathrm{C}$ and $\delta^{15} \mathrm{~N}$ values, respectively, both $\left.\mathrm{p}<0.0001\right)$. Most of the feathers clustered within Group 3 (70\%), followed by Group $1(20 \%)$, with feathers from the former group having much higher $\delta^{13} \mathrm{C}$ and $\delta^{15} \mathrm{~N}$ values than those of the latter (Multiple comparison tests of mean ranks, both $\mathrm{p}=0.001$ ). A few feathers (Group 2, 10\%) had intermediate isotopic signatures (Table 2, Fig. 4B)

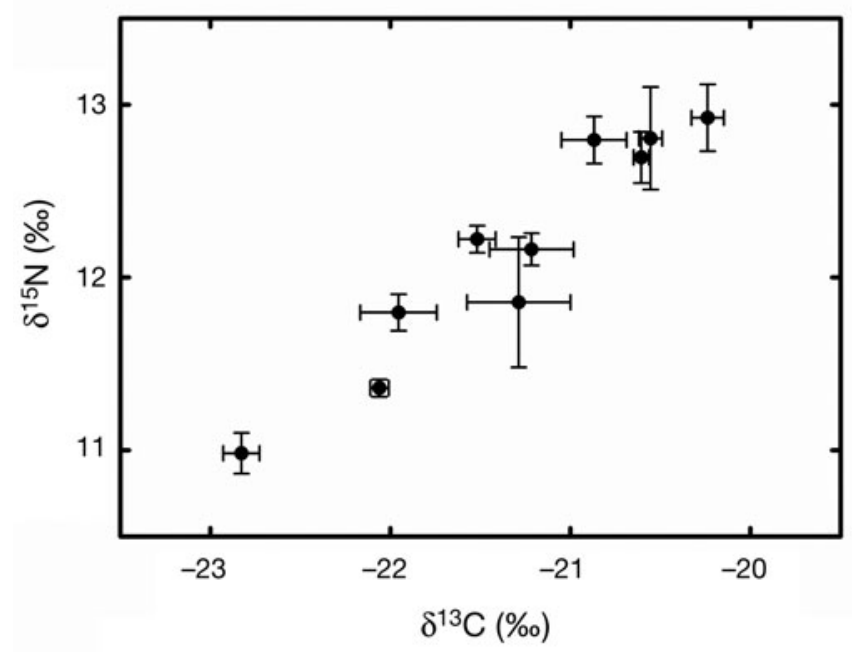

Fig. 3. Procellaria aequinoctialis. Stable carbon and nitrogen isotope values of 10 chicks of white-chinned petrel (WCP) from Possession Island. Values are mean \pm SD from 4 body feathers per bird 

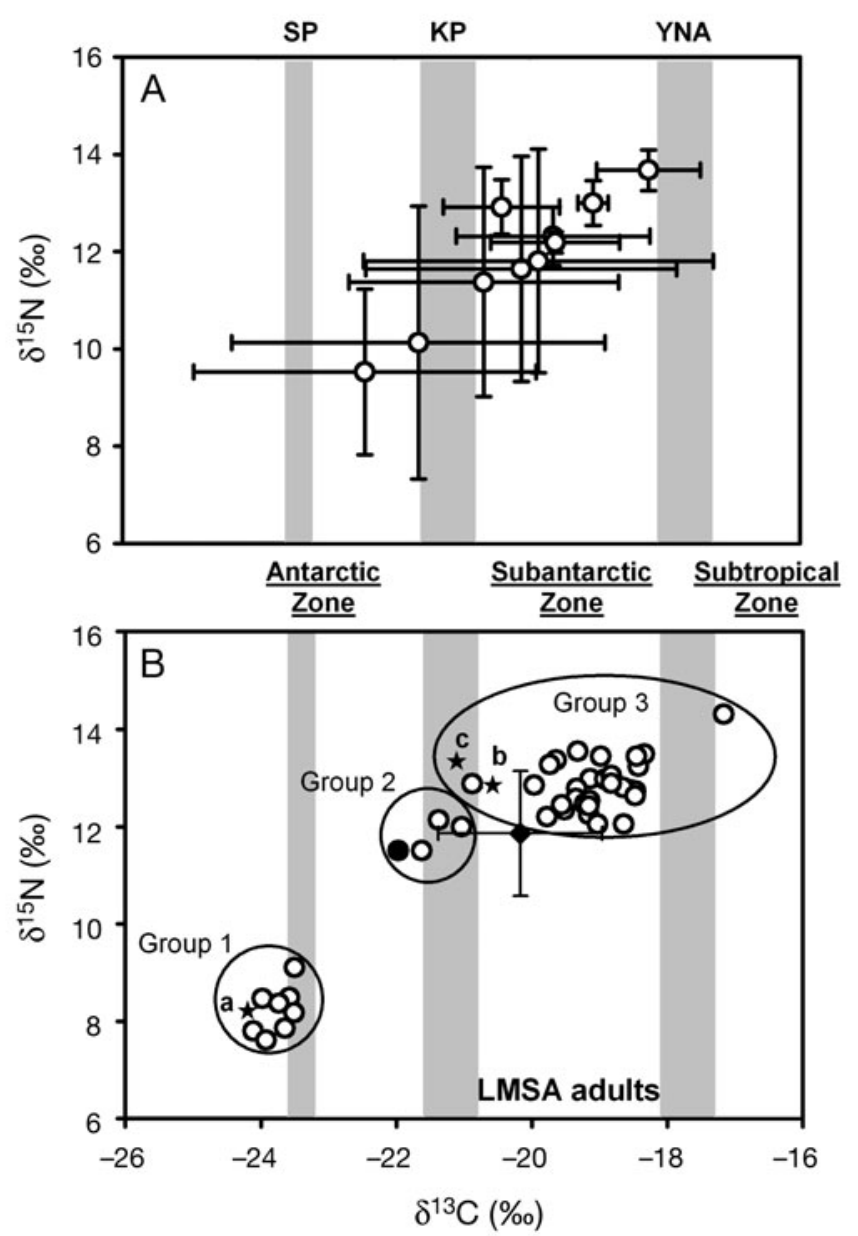

Fig. 4. Phoebetria palpebrata. Stable carbon and nitrogen isotope values of adults of light-mantled sooty albatross (LMSA) from Possession Island. (A) Mean \pm SD values from 4 body feathers per bird $(n=10)$. (B) Isotopic signature of all the individual body feathers $(\mathrm{n}=40)$. $(\star)$ and $(\bullet)$ : signature of 3 different parts of the same body feather (a: distal, b: middle, c: proximal), and the mean value for that feather, respectively. $(\checkmark)$ Calculated mean $( \pm \mathrm{SD})$ with each individual value resulting from the mean (= pool) of 4 body feathers per bird. Estimated foraging zones are indicated between the 2 panels. The signatures of snow petrels (SP), king penguins (KP) and yellow-nosed albatrosses (YNA) illustrate the $\delta^{13} \mathrm{C}$ values of species known to forage in the high-Antarctic Zone, at the Polar Front and in the Subtropical Zone, respectively (grey bars represent the species' $\delta^{13} \mathrm{C}$ standard deviations)

\section{DISCUSSION}

\section{Isotopic niches during the breeding and moulting periods}

The mean isotopic signatures of chick and adult body feathers highlighted trophic segregation and contrasted seasonal strategies of Southern Ocean procellariiforms. During breeding, chick $\delta^{13} \mathrm{C}$ and $\delta^{15} \mathrm{~N}$ values defined 2 foraging areas and 2 trophic levels, respectively, thus allowing characterisation of 3 distinct isotopic niches for the 4 species. The first segregating mechanism operates at the spatial scale. Using latitudinal variations in $\delta^{13} \mathrm{C}$ values of marine organisms in the Southern Hemisphere (Cherel \& Hobson 2007, Quillfeldt et al. 2008), the data indicate that LMSA and WCP foraged in more southern waters than WA and SA. The second mechanism operates through resource partitioning, with WA feeding at a higher trophic level than SA. Accordingly, WA chicks are mainly fed with large squids (Cherel \& Weimerskirch 1999), while SA food is mostly composed of smaller squids and carrion of planktivorous seabirds (Ridoux 1994), which have lower nitrogen signatures (Cherel et al. 2002, 2007, 2008a). In contrast, the $\delta^{15} \mathrm{~N}$ values of LMSA and WCP chicks were almost identical. Their diet differed however, with LMSA feeding more on cephalopods and WCP more on fish (Ridoux 1994), thus illustrating the limit of the stable isotope method that is most powerful when combined with conventional approaches (Bearhop et al. 2004).

The feather isotopic signature of chicks integrates the feeding ecology of both parent birds when they feed for their offspring. The chick isotopic niche is thus potentially different from the adult isotopic niche during the chick-rearing period and it cannot detail sexual foraging differences and the diet of adult birds when they forage for themselves (Weimerskirch et al. 1997, Cherel et al. 2005). Nonetheless, the chick isotopic niches indicated the origin of the food assimilated by the chick, thus underlining the key habitats used by adult birds when they forage for their offspring. WA and SA adults have been satellite-tracked in the Subantarctic and Subtropical Zones during the chick-rearing period (Weimerskirch 1998), but the chick $\delta^{13} \mathrm{C}$ values were subantarctic, showing little influence of subtropical prey and reflecting a diet primarily based on squids (and penguins) taken by the adults in the vicinity of the Crozet islands (Ridoux 1994, Weimer-

Table 2. Phoebetria palpebrata. Stable carbon and nitrogen isotope values of individual body feathers of adults of lightmantled sooty albatross from Possession Island. Body feathers were grouped using a hierarchical clustering analysis (see 2nd section of 'Results'). Values in the same column not sharing a common superscript letter are significantly different $(p<0.001)$. Values are mean \pm SD

\begin{tabular}{|c|c|c|c|c|}
\hline \multicolumn{3}{|c|}{$\begin{array}{l}\text { Number of feathers } \\
\text { (n) }\end{array}$} & $\begin{array}{c}\delta^{13} \mathrm{C} \\
(\% \circ)\end{array}$ & $\begin{array}{c}\delta^{15} \mathrm{~N} \\
(\% \circ)\end{array}$ \\
\hline Group 1 & 8 & 20.0 & $-23.7 \pm 0.2^{\mathrm{a}}$ & $8.2 \pm 0.5^{\mathrm{a}}$ \\
\hline Group 2 & 4 & 10.0 & $-21.2 \pm 0.3^{\mathrm{b}}$ & $12.1 \pm 0.6^{\mathrm{b}}$ \\
\hline Group 3 & 28 & 70.0 & $-19.0 \pm 0.6^{\mathrm{c}}$ & $12.9 \pm 0.5^{\mathrm{b}}$ \\
\hline Total & 40 & 100.0 & $-20.2 \pm 2.0$ & $11.9 \pm 1.9$ \\
\hline
\end{tabular}


skirch et al. 1997). Another strategy was used by LMSA and WCP. The carbon signature of their chicks was intermediate between subantarctic and Antarctic values, suggesting that both subantarctic and Antarctic prey were important for the chick nutrition. Indeed, both satellite-tracking and the presence of Antarctic krill Euphausia superba in food samples showed that birds forage within the Antarctic and Subantarctic Zones during the chick-rearing period (Ridoux 1994, Weimerskirch 1998, Catard et al. 2000).

In contrast to the breeding period, the albatrosses and petrel were all segregated during the moulting period, with mean adult feather $\delta^{13} \mathrm{C}$ and $\delta^{15} \mathrm{~N}$ values characterising 4 statistically distinct isotopic niches. Comparison of the $\delta^{13} \mathrm{C}$ values with those of the control species demonstrated that LMSA moulted within the Southern Ocean, while both WA and SA moulted in oceanic subtropical waters. The moulting isotopic niche of WA was identical in 2003 (Jaeger et al. 2009) and 2005 (this study), suggesting little inter-annual variations in its feeding ecology. Interestingly, while WA and SA foraged in the same habitats during both the breeding and moulting periods, the same segregating mechanism operates during the 2 periods in 2 different water masses, with WA always feeding at a higher trophic level than SA. Finally, the moulting isotopic niche of WCP was very distinctive and characterised by high $\delta^{13} \mathrm{C}$ and $\delta^{15} \mathrm{~N}$ values, which strongly suggests foraging in a productive area marked by high $\delta^{13} \mathrm{C}$ and $\delta^{15} \mathrm{~N}$ baseline levels. Indeed, the few band recoveries of Crozet birds showed that WCP visit the Benguela upwelling system in winter (Weimerskirch et al. 1985), and the carbon signature of WCP was identical to that of Cape gannets that forage over the South African shelf (Jaquemet \& McQuaid 2008). Noticeably, the winter $\delta^{15} \mathrm{~N}$ value of WCP was higher than that of Cape gannets, which is in agreement with WCP feeding on larger fish and cephalopods, and gannets preferring smaller epipelagic shoaling fish, both species also relying on fishery discards (Jackson 1988, Pichegru et al. 2007).

In conclusion, comparison of chick and adult isotopic niches within each species underline 3 different yearround strategies for albatrosses and petrels. 'Southern Ocean resident' species, like LMSA, forage mainly all year long within the limits of the Southern Ocean. Most species however migrate north of the Subtropical Front, with the 'oceanic migrants' (e.g. WA and SA) foraging predominantly in oceanic subtropical waters during moult, and the 'neritic migrants' (WCP) primarily moulting over productive shelf waters. This classification is in agreement with the few studies using geolocators, which showed that the grey-headed albatross can be classified as a Southern Ocean resident, and WCP and the black-browed albatross as neritic migrants (Croxall et al. 2005, Phillips et al. 2005, 2006).

\section{Isotopic specialists and generalists}

Despite the wide range of individual dietary specialisations, indices of the level of specialisation are available for only a few species, including some seabirds (Bolnick et al. 2003, Woo et al. 2008). The present work shows that the TNW of most adults of the procellariiforms was low, indicating that populations were isotopic specialists and that WIC was almost negligible during moulting. For example, the very low TNW of WCP adults indicates that the population moults in an isotopically restricted area where all the birds have similar feeding habits, as previously suggested for moulting black-browed albatrosses (Cherel et al. 2000). The larger variances of WCP chicks and larger TNW of LMSA adults were 2 exceptions to these general features.

The moderate variance of WCP chicks indicates an isotopic generalist population during the breeding period. Individual WCP chicks segregate by their feather isotopic signatures, thus indicating individual/pair specialisation. This unexpected finding raises new questions about the summer biology of WCP. Our results indicate consistent foraging behaviour of adult individuals/pairs during chick moult (i.e. during the mid to late chick-rearing period), an issue that has rarely been investigated in the past (Quillfeldt et al. 2008, Woo et al. 2008). The linear and positive relationship between chick $\delta^{13} \mathrm{C}$ and $\delta^{15} \mathrm{~N}$ values suggests a mixing of 2 isotopically distinct sources (Fry 2006). Based on the known feeding ecology of WCP (Ridoux 1994, Catard et al. 2000), the 2 sources are likely to be Antarctic krill in high-Antarctic waters and various fish and squid in subantarctic waters, the 2 kinds of prey having lower and higher $\delta^{13} \mathrm{C}$ and $\delta^{15} \mathrm{~N}$ values, respectively (Cherel et al. 2008a).

LMSA adults presented a very large inter-nesting TNW with a higher WIC than BIC, as illustrated by the high overlap among individual isotopic niches. LMSA are thus isotopic generalists both at the population and individual levels, and the method shed a new light on their feeding ecology during moult. The large range of $\delta^{13} \mathrm{C}$ values shows that LMSA dispersed widely, from the Antarctic to the Subantarctic Zones and, in rare cases, to the Subtropical Zone (1 feather). Two main foraging areas were nevertheless primarily used, i.e. subantarctic waters (Group 3 feathers) followed by highAntarctic waters (Group 1). Since latitudinal variation in baseline $\delta^{15} \mathrm{~N}$ level is relatively low in the Southern Ocean (Lourey et al. 2003), the large $\delta^{15} \mathrm{~N}$ difference between the 2 groups of LMSA feathers indicates feeding on different prey in the 2 foraging zones. Firstly, in Antarctica (Group 1), birds most likely fed on Antarctic krill, their feather nitrogen isotopic value (8.2\%) being close to the blood $\delta^{15} \mathrm{~N}$ ratio of Adélie penguins when 
they prey upon euphausiids (7.9\%, Cherel 2008). Secondly, LMSA fed on higher trophic level prey, most likely fish and squid, when they foraged in northern subantarctic waters (Group 3). A few LMSA feathers had intermediate isotopic signatures (Group 2), suggesting either that some birds moulted in a latitudinal area intermediate between the high-Antarctic and Subantarctic Zones (Hypothesis 1), or, alternatively, that feathers grew while the birds shifted from one zone to the other, thus integrating the 2 different environments (Hypothesis 2). To test the 2 hypotheses, we measured the $\delta^{13} \mathrm{C}$ and $\delta^{15} \mathrm{~N}$ values of 3 different parts (proximal, medium and distal parts) of 6 body feathers from 6 individual birds. Five feathers showed low intrafeather $\delta^{13} \mathrm{C}$ variances $(<0.5 \%)$, indicating that their growth period took place within a given water mass (4 and 1 in the Subantarctic and Subtropical Zones, respectively). Isotopic variances within the remaining feather were much higher $\left(1.9\right.$ and $2.9 \%$ for $\delta^{13} \mathrm{C}$ and $\delta^{15} \mathrm{~N}$, respectively), with the resulting average values being intermediate (-22.0 and $11.5 \%$ ) and identical to those of feather Group 2. A hierarchical clustering analysis (Ward's method) classified the distal (oldest) part with feather Group 1 and the median and proximal (youngest) parts with Group 3 (Fig. 4). Hence, the bird migrated from the Antarctic to the Subantarctic Zones and used the 2 well-defined isotopic moulting areas and diets, thus verifying Hypothesis 2.

The moulting niche of LMSA illustrates well the utility of measuring the isotopic signature of several body feathers per bird in the case of isotopic generalist populations (Jaeger et al. 2009). The usual method of pooling several body feathers cannot provide information about one of the 2 contrasted moulting environments of LMSA, i.e. feeding on krill in Antarctica (Fig. 4). The data also showed that using individual feathers can exhibit the same negative integrative aspect, but at a smaller time scale. From a practical point of view, individual body feathers depicted the foraging behaviour of moulting LMSA well, with Group 2 (intermediate isotopic values that integrate the signature of the 2 habitats and diets) constituting no more than $10 \%$ of the total number of feathers. Hence, analysing several whole body feathers for generalist populations is a good compromise to maximise ecological information, while minimising the numbers of sampled birds and isotopic measurements (Jaeger et al. 2009). Future research is needed to determine the timing and temporal extent of body feather moult during the inter-nesting period to facilitate interpretation of feather stable isotope ratios at a higher temporal resolution.

Acknowledgements. The authors thank Y. Perrot and G. Dorémus for collecting albatross and petrel feathers in the field, and G. Guillou for running stable isotope samples. The manuscript benefitted from thoughtful comments by S. Oppel and 3 anonymous reviewers. The present work was supported financially and logistically by the program REMIGE-ANR Biodiversité 2005-011 (H. Weimerskirch), the Institut Polaire Français Paul Emile Victor (IPEV, programme no. 109, H. Weimerskirch) and the Terres Australes et Antarctiques Françaises (TAAF).

\section{LITERATURE CITED}

Barbraud C, Weimerskirch H (2003) Climate and density shape population dynamics of a marine top predator. Proc Biol Sci 270:2111-2116

Barbraud C, Marteau C, Ridoux V, Delord K, Weimerskirch H (2008) Demographic response of a population of whitechinned petrels Procellaria aequinoctialis to climate and longline fishery bycatch. J Appl Ecol 45:1460-1467

Bearhop S, Adams CE, Waldron S, Fuller RA, MacLeod H (2004) Determining trophic niche width: a novel approach using stable isotope analysis. J Anim Ecol 73:1007-1012

Bolnick DI, Yang LH, Fordyce JA, Davis JM, Svanback R (2002) Measuring the individual-level resource specialization. Ecology 83:2936-2941

Bolnick DI, Svanback R, Fordyce JA, Yang LH, Davis JM, Hulsey CD, Forister ML (2003) The ecology of individuals: incidence and implications of individual specialization. Am Nat 161:1-28

Bost CA, Georges JY, Guinet C, Cherel Y and others (1997) Foraging habitat and food intake of satellite-tracked king penguins during the austral summer at Crozet Archipelago. Mar Ecol Prog Ser 150:21-33

Bridge ES (2006) Influences of morphology and behavior on wing-molt strategies in seabirds. Mar Ornithol 34:7-19

Catard A, Weimerskirch H, Cherel Y (2000) Exploitation of distant Antarctic waters and close shelf-break waters by white-chinned petrels rearing chicks. Mar Ecol Prog Ser 194:249-261

> Cherel Y (2008) Isotopic niches of emperor and Adélie penguins in Adélie Land, Antarctica. Mar Biol 154:813-821

Cherel Y, Hobson KA (2007) Geographical variation in carbon stable isotope signatures of marine predators: a tool to investigate their foraging areas in the Southern Ocean. Mar Ecol Prog Ser 329:281-287

Cherel Y, Weimerskirch H (1999) Spawning cycle of onychoteuthid squids in the southern Indian Ocean: new information from seabird predators. Mar Ecol Prog Ser 188:93-104

Cherel Y, Hobson KA, Weimerskirch H (2000) Using stableisotope analysis of feathers to distinguish moulting and breeding origins of seabirds. Oecologia 122:155-162

Cherel Y, Bocher P, de Broyer C, Hobson KA (2002) Food and feeding ecology of the sympatric thin-billed Pachyptila belcheri and Antarctic P. desolata prions at Iles Kerguelen, Southern Indian Ocean. Mar Ecol Prog Ser 228:263-281

Cherel Y, Hobson KA, Weimerskirch H (2005) Using stable isotopes to study resource acquisition and allocation in procellariiform seabirds. Oecologia 145:533-540

Cherel Y, Phillips RA, Hobson KA, McGill R (2006) Stable isotope evidence of diverse species-specific and individual wintering strategies in seabirds. Biol Lett 2:301-303

Cherel Y, Hobson KA, Guinet C, Vanpé C (2007) Stable isotopes document seasonal changes in trophic niches and winter foraging individual specialisation in diving predators from the Southern Ocean. J Anim Ecol 76:826-836

Cherel Y, Ducatez S, Fontaine C, Richard P, Guinet C (2008a) Stable isotopes reveal the trophic position and mesopelagic fish diet of female southern elephant seals breed- 
ing on the Kerguelen Islands. Mar Ecol Prog Ser 370: 239-247

> Cherel Y, Le Corre M, Jaquemet S, Ménard F, Richard P, Weimerskirch H (2008b) Resource partitioning within a tropical seabird community: new information from stable isotopes. Mar Ecol Prog Ser 366:281-291

> Croxall JP, Silk JRD, Phillips RA, Afanasyev V, Briggs DR (2005) Global circumnavigations: tracking year-round ranges of nonbreeding albatrosses. Science 307:249-250

Delord K, Besson D, Barbraud C, Weimerskirch H (2008) Population trends in a community of large Procellariiforms of Indian Ocean: potential effects of environment and fisheries interactions. Biol Conserv 141:1840-1856

> Durell SEA le V dit (2000) Individual feeding specialisation in shorebirds: population consequences and conservation implications. Biol Rev Camb Philos Soc 75:503-518

Fry B (2006) Stable isotope ecology. Springer Verlag, New York

> Gladbach A, McGill RAR, Quillfeldt P (2007) Foraging areas of Wilson's storm-petrel Oceanites oceanicus in the breeding and inter-breeding period determined by stable isotope analysis. Polar Biol 30:1005-1012

Grosbois V, Thompson PM (2005) North Atlantic climate variation influences survival in adult fulmars. Oikos 109: 273-290

> Hedd A, Montevecchi WA (2006) Diet and trophic position of Leach's storm-petrel Oceanodroma leucorhoa during breeding and moult, inferred from stable isotope analysis of feathers. Mar Ecol Prog Ser 322:291-301

> Hobson KA, Piatt JF, Pitocchelli J (1994) Using stable isotopes to determine seabird trophic relationships. J Anim Ecol 63:786-798

> Jackson S (1988) Diets of the white-chinned petrel and sooty shearwater in the southern Benguela Region, South Africa. Condor 90:20-28

Jaeger A, Blanchard P, Richard P, Cherel Y (2009) Using carbon and nitrogen isotopic values of body feathers to infer inter- and intra-individual variations of seabird feeding ecology during moult. Mar Biol 156:1233-1240

> Jaquemet S, McQuaid C (2008) Stable isotope ratios in Cape gannets around the southern coasts of Africa reveal penetration of biogeographic patterns in oceanic signatures. Estuar Coast Shelf Sci 80:374-380

> Lourey MJ, Trull TW, Sigman DM (2003) Sensitivity of $\delta^{15} \mathrm{~N}$ of nitrate, surface suspended and deep sinking particulate nitrogen to seasonal nitrate depletion in the Southern Ocean. Global Biogeochem Cycles 17:1081-1098

McCutchan JH, Lewis WM, Kendall C, McGrath CC (2003) Variation in trophic shift for stable isotope ratios of carbon, nitrogen, and sulphur. Oikos 102:378-390

Newsome SD, Martinez del Rio C, Bearhop S, Phillips DL (2007) A niche for isotopic ecology. Front Ecol Environ 5: 429-436

Park YH, Gambéroni L (1997) Cross-frontal exchange of Antarctic Intermediate Water and Antarctic Bottom Water in the Crozet Basin. Deep-Sea Res II 44:963-986

Phillips RA, Silk JRD, Croxall JP, Afanasyev V, Bennett VJ

Editorial responsibility: John Piatt,

Anchorage, Alaska, USA
(2005) Summer distribution and migration of nonbreeding albatrosses: individual consistencies and implications for conservation. Ecology 86:2386-2396

Phillips RA, Silk JRD, Croxall JP, Afanasyev V (2006) Yearround distribution of white-chinned petrels from South Georgia: relationships with oceanography and fisheries. Biol Conserv 129:336-347

Pichegru L, Ryan PG, van der Lingen CD, Coetzee J, RopertCoudert Y, Grémillet D (2007) Foraging behaviour and energetics of Cape gannets Morus capensis feeding on live prey and fishery discards in the Benguela upwelling system. Mar Ecol Prog Ser 350:127-136

> Pinaud D, Cherel Y, Weimerskirch H (2005) Effect of environmental variability on habitat selection, diet, provisioning behaviour and chick growth in yellow-nosed albatrosses. Mar Ecol Prog Ser 298:295-304

Quillfeldt P, McGill RAR, Masello JF, Weiss F, Strange IJ, Brickle P, Furness RW (2008) Stable isotope analysis reveals sexual and environmental variability and individual consistency in foraging of thin-billed prions. Mar Ecol Prog Ser 373:137-148

Ridoux V (1994) The diets and dietary segregation of seabirds at the subantarctic Crozet Islands. Mar Ornithol 22:1-192

Ridoux V, Offredo C (1989) The diets of five summer breeding seabirds in Adélie Land, Antarctica. Polar Biol 9:137-145

Rolland V, Barbraud C, Weimerskirch H (2008) Combined effects of fisheries and climate on a migratory long-lived marine predator. J Appl Ecol 45:4-13

Rubenstein DR, Hobson KA (2004) From birds to butterflies: animal movement patterns and stable isotopes. Trends Ecol Evol 19:256-263

Warham J (1990) The petrels. Their ecology and breeding systems. Academic Press, London

Warham J (1996) The behaviour, population biology and physiology of the petrels. Academic Press, London

Weimerskirch H (1998) Foraging strategies of Indian Ocean albatrosses and their relationships with fisheries. In: Robertson G, Gales R (eds) Albatross biology and conservation. Surrey Beatty \& Sons, Chipping Norton, New South Wales, Australia, p 168-179

Weimerskirch H, Jouventin P, Mougin JL, Stahl JC, Van Beveren $M$ (1985) Banding recoveries and the dispersal of seabirds breeding in French Austral and Antarctic Territories. Emu 85:22-33

Weimerskirch H, Cherel Y, Cuénot-Chaillet F, Ridoux V (1997) Alternative foraging strategies and resource allocation by male and female wandering albatrosses. Ecology 78:2051-2063

Widelitz RB, Jiang TX, Yu M, Shen T and others (2003) Molecular biology of feather morphogenesis: a testable model for evo-devo research. J Exp Zool Mol Dev Evol 298B: 109-122

Woo KJ, Elliott KH, Davidson M, Gaston AJ, Davoren GK (2008) Individual specialization in diet by a generalist marine predator reflects specialization in foraging behaviour. J Anim Ecol 77:1082-1091

Submitted: March 17, 2009; Accepted: October 20, 2009

Proofs received from author(s): February 8, 2010 